\title{
Millî Eğitim Şûralarında Eğitim Finansmanı Sorunu
}

\section{Muzaffer DENIZ*}

Öz: İlki 1939, sonuncusu da 2014 yılında toplam 19 kez düzenlenen Millî Eğitim Şûraları, Türk eğitim tarihi içerisinde önemli bir yere sahiptir. Millî Eğitim Bakanlığının ve Türk millî eğitim sisteminin en yüksek danışma organıdır. Şûralara, Millî eğitimle ilgili politikaların çizilmesinde yol gösterici rolü verilmiştir. Eğitim Şûraları ile ilgili belirtilmesi gereken bir olgu da her ne kadar resmî bir yapılanma olsa da eğitimle ilgili diğer kişi ve kuruluşların, sendikaların, işveren örgütlerinin, sivil toplum örgütlerinin, özel girişim temsilcilerinin, akademisyenlerin de katılımının olmasıdır.

Bu çalışmada; önce giriş bölümünde eğitimin finansmanı hakkında bilgilere sonra şûralar hakkında genel bilgilere yer verilmiştir. Daha sonra da gündemini eğitim finansmanı konusunun oluşturduğu şûralarla, bir şekilde eğitim finansmanı konusuna değinilen şûralar ele alınmıştır. Burada hangi önerilerin, temennilerin dile getirilmiş olduğu ve sonucunda bunların hangilerinin yaşama geçirildiği irdelenmiştir.

Bunca eğitim şûrasında görüşülmesine, resmî kurum ve kişilerin dışında eğitimle ilgili diğer paydaşların da katılımına ve kat edilen ekonomik büyüklüğe rağmen Türkiye'de eğitimin finansmanı probleminin çözülemeyip sonraki kuşaklara aktarılan bir sorun olarak kaldığı görülmüştür.

Anahtar kelimeler: Türkiye, Şûralar, Millî Eğitim, Finansman Sorunu

\section{Educational Finance Issue in National Education Congresses}

Abstract: National Education Congresses are very important for Turkish Education History. First National Education Congress was in 1939 and the last one was in 2014. It is the superior consultation board of National Education Ministry and Turkish National Education System. Congresses' mission is to lead the politics about National Education. Another fact about

\footnotetext{
* Dr. Öğr. Üyesi, Van Yüzüncü Yıl Üniversitesi Eğitim Fakültesi Tarih Öğretmenliği Bölümü, e mail: mdeniz@yyu.edu.tr, orcid no: 0000-0001-9331-7012
} 
congresses is even though it's formal; it also includes other people or establishments such as unions, organizations, civil society organizations, private establishments and academicians.

This study first gives information about education finance and then information about congresses. After that the study refers to congresses about educational finance only and congresses which include topics about educational finance. This study contains suggestions and requests from those congresses and we will see which suggestions or requests are fulfilled.

Yet after all that effort in congresses and all of the non-governmental people or establishments contribution to the subject, educational finance issue in Turkey has not being solved and transferred to the next generations.

Keywords: Turkey, Congresses, National Education, Finance Issue

\section{Giriş}

Eğitim finansmanı denilince eğitim için kaynak bulunması/yaratılması ve bu kaynakların verimli ve adil bir şekilde kullanılması akla gelmektedir. Eğitim finansmanı bir ekonomik etkinlik olarak ele alınacak olursa bu uzun vadeli bir yatırım olarak karşımıza çıkar. Sonuçlarını kısa sürede görmek mümkün değildir. Yine eğitim, ekonomik açıdan tek tek vatandaşların hayat standardını geliştirmenin yanı sıra, belki bundan da önemlisi ülkenin refah düzeyini yükseltilmesi için gerekli temel taşlardan birisidir. Bir başka nokta ise eğitim, devletin aslî görevlerinden biri olup bu alana, yalnızca bir ekonomik etkinlik olarak da bakılamaz. Devlet her vatandaşına, en azından temel eğitimi vermekle mükelleftir. Ekonomi, finansman ya da başka nedenlerle hiçbir vatandaşını temel eğitimden yoksun bırakamaz.

Eğitimin finansmanı bütün ülkeler için en önemli sorunlardan biridir. Bu sorun az gelişmiş ülkelerde ise hayatî derecede önemli bir soruna dönüşebilmektedir. Azgelişmiş ülkeler mevcut finansman sorunlarının yanı sıra nüfus artışının getirdiği yeni finans sorunlarını da gögüslemek zorunda kalmaktadırlar. Bazı gelişmiş ülkelerde negatif nüfus artışı ile atıl kapasitelerle karşılaşabilirken, az gelişmiş ülkeler nüfuslarına her yıl eklenen yüzbinlerce, milyonlarca nüfusuna yeni okul ve öğretmen için yeni yatırımlar yapmak zorundadırlar. Yeni okul yapmak, sadece, okul binası yapmaktan ibaret olmayı belki daha fazla yatırımı okul binası içinde öğrenci sıralarından, bilişim teknolojilerine, laboratuvarlara, dersliklerdeki materyallere kadar her bir yatırım kalemini, dolayısıyla eğitim finansmanını arttırmaktadır. Bundan başka işletme giderleri de azımsanacak boyutta değildir. Ayrıca, okullarda öğretmen ve diğer eğitim çalışanların istihdam giderlerini de buna eklemek gerekir. 
Eğitimin finansmanı için bunca yatırım yapılması, ülke ekonomisinin büyüyüp gelişmesi, nitelikli iş gücünün artması, siyasal bilinç ve sosyal barışı getirmesi gibi çıktılar sağlaması için olduğu kadar, aynı zamanda yukarıda da söylendiği gibi devlet olmanın bir zorunluluğudur.

Türkiye'de eğitimin finansmanı için genelde kamu kaynakları kullanılmaktadır. Özel girişim, dershane, vakıf ve kurumların da katkısı her geçen gün artmakla birlikte büyük ölçüde devletin inisiyatifi ve sorumluluğundadır. Bağış, katkı payı, giderlere katılma, harç gibi halkın dolaylı katkıları da azımsanmayacak boyuttadır. Burada bir başka sorun ortaya çıkmakta, halkın bu dolaylı katkıları her zaman gönüllülük esasına dayanmamaktadır. Bütün bunların yanı sıra halkın katkısı her yerde eşit olmamakta, okulların bulunduğu bölge ve yarattıkları imaja göre farklılıklar ve dolayısıyla okullar arasında eşitsizliklere de neden olmaktadır. Bir başka eşitsizlik örneği ise özel okullardır.

Yukarıda değinildiği üzere eğitimin finansmanı büyük boyutuyla devlet kaynakları ile sağlanmakta olup, arzu edilen başarıların sağlanmasının önkoşullarından biri eğitime aktarılacak parasal kaynakların temini olmuştur. Ancak Osmanlıdan devralınan mevcut durum ve sonraki dönemdeki az gelişmiş bir ekonomik yapı dolayısıyla cumhuriyet hükümetlerinin bütçeden eğitime ayırabildiği pay hep düşük kalmıştır. 1950’lere kadar eğitimin bütçeden aldığı pay hiçbir zaman yüzde 10'u geçememiştir. Cumhuriyetin ilk y1llarında ise bu oran yüzde 5'ler düzeyinde kalmıştır (Adem, 1993). Ayrıca Osmanlı Devletinden devralınan borçlarından ${ }^{1}$ kaynaklanan sıkıntılar, yetişmiş iş gücünün savaşlarda kaybedilmesi, II. Dünya Savaşı yıllarında bütçenin büyük bölümü savunmaya ayrılması mecburiyetinin ${ }^{2}$ getirdiği sıkıntılar gibi olumsuzlukların etkisi büyük olmuştur.

I. ve II. Millî Eğitim Şûraları zamanında bütçe giderleri (lira)

\begin{tabular}{|l|l|l|l|}
\hline Bütçe yılı & Düyun-1 Umumiye & Millî Eğitim Bakanlığı & Toplam bütçe gideri \\
\hline
\end{tabular}

\footnotetext{
${ }^{1} \mathrm{Bu}$ şekilde başlayan borçlanma yeni devlete miras olarak Lozan Antlaşması ile Türkiye Osmanlı borçlarının yüzde 62'sini ödemeyi kabullenmek zorunda birakılınca cumhuriyet hükümetleri 1929'dan 1944'e kadar 15 yıl boyunca bütçenin ortalama yüzde 15 'ini her yıl yurtdışına göndermiştir. Bkz. İlhan Başgöz, “Türkiye'nin Eğitim Çıkmazı ve Atatürk,” Kültür B. Yayınları, Ankara 1995, s. 62.

2 "II. Dünya Savaşının ilk yıllarından itibaren sekiz yıl boyunca devlet bütçesinin yarısına yakını, vatan savunmasına ayrılmaktadır.” Bkz. "Kazım Öztürk, Türkiye Cumhuriyeti Hükümetleri ve Programları, Ak Yayınları, İstanbul 1968, s. 327-328.”
} 
YYÜ Eğitim Fakültesi Dergisi (YYU Journal of Education Faculty), 2019; 16(1):171-201, http://efdergi.yyu.edu.tr

\begin{tabular}{|l|r|r|r|}
\hline $1939^{3}$ & 49.739 .599 & 16.111 .000 & 261.064 .192 \\
\hline $1942^{4}$ & 95.279 .219 & 27.653 .734 & 384.035 .101 \\
\hline
\end{tabular}

Yukarıdaki tablo herhangi bir yoruma gerek bırakmayarak mevcut durumu göz önüne sermektedir. Burada da görüldüğü üzere yeni devlete kalan miras belliydi ve cumhuriyeti kuranların önem verdikleri konuların başında eğitim olduğu halde 1940'a gelindiğinde 40.000 köyün ancak 8.000’inde okul mevcuttu.

Eğitimin ilerlemesini, özellikle ilköğretimin gelişmesini finansal açıdan engelleyen diğer önemli bir etken, ilköğretimin giderlerinin bir Osmanlı mirası olarak genel bütçeye alınmayarak il idare kurullarına (vilâyet genel meclisleri) bırakılmasıdır. Ancak yapılan çeşitli düzenlemelere karşın parasal yönden gittikçe zayıflayan mahallî idareler ilköğretim masraflarını karşılayamayacak duruma düşmüşler, bazı vilâyetler öğretmen kadrolarını azaltmak, okul kapatmak mecburiyetinde kalmış, hatta öğretmen maaşlarını bile ödeyememişlerdir (Milli Eğitim Bakanlığı [MEB], İlköğretim Kanunu Tasarısı'nın Gerekçeleri, 1961). Nihayet dönemin sonuna doğru, 1948'de 5166 sayılı kanunla ilkokul öğretmenlerinin maaşları genel bütçeye alınabilmişti.

1950 sonrasında ise alınan dış borçların iyi kullanılmaması, zamanla borçların faizlerinin bile ödenememesi, bir dönem siyasilerin sıklıkla vurguladığı gibi “ülkenin 70 cent'e muhtaç olması", yeterli zenginliklere sahip olmaması, iyi yönetilememesi gibi nedenlerle ve ülkenin gerekli ekonomik gelişmeyi bir türlü sağlayamaması ile karşı karşıya kalmıştır. Bunun sonucunda bütçe denkliği sağlanamamış ve diğer alanlara olduğu gibi eğitim alanına da yeterli kaynak aktarılamamıştır.

Eğitime yeterli kaynak yaratılamaması okullaşma oranları, ikili üçlü eğitim, kalabalık sınıflar, yetersiz donanım ve eğitim ortamlar şeklinde kendini göstermiştir. Bu yapı günümüzde de devam etmektedir. Anaokulları dâhil olmak üzere üniversiteler dışında her düzeyde okulların yarısından çoğu kalabalık sınıflarda ikili eğitim vermektedir.

Bütün Cumhuriyet tarihi boyunca eğitimin finansmanı Türkiye için hep sorun olarak kalmıştır. Bir taraftan da dolaylı yoldan -gönüllülük esasına pek de uymayan biçimiyle- halkın katkıları ile finansman sorunları çözülmeye çalışılmaktadır. Ayrıca her yıl ülke nüfusuna

\footnotetext{
3 “Maarif Vekilliği 1939 Mali Yılı Bütçesi ve Müzakere Zabıtları, Maarif Matbaası, İstanbul 1939, s. 97.”

4 “Maarif Vekilliği 1942 Mali Yılı Bütçesi ve Müzakere Zabıtlarl, Maarif Matbaası, Ankara 1942, s. 94.”
} 
katılan bir milyon kişinin de mevcut finansman sorunlara ilave yük getirdiği de göz ardı edilmemelidir.

Buradan çıkarılacak sonuç; eğitimin finansmanı ile ilgili onlarca düzenleme yapılmış, eğitim şûralarında konu enine boyuna tartışılmış olmasına karşın bu konuda nihai bir çözüm ortaya konulamadığıdır. Bunda da ülkenin kıt kaynakları ile eğitimin finansmanı için mevcut talep arasında karşılanması mümkün olmayan fark, dengesizlik Cumhuriyet tarihi boyunca giderilemediğinden eğitim finansmanı problemi incelenen dönem boyunca çözülememiş ve çözülmesi gereken önemli bir problem olarak hep sonraki dönemlere aktarılmıştır.

\section{Yöntem}

Bu araştırmada 1939 yılında yapılan ilk Millî Eğitim Şûrası ile 2014 yılında yapılan son Millî Eğitim Şûrası kararları araştırma desenini oluşturmaktadır. Bu süre içerisinde yapılmış olan toplam 19 şûrada yapılan görüşmeler, komisyon çalışmaları ve alınan kararlar incelenmiş olup bunlardan sadece eğitimin finansmanı konusunu gündeminde alan şûralar üzerinde çalışma yapılmıştır. Bunların dışında diğer kaynaklara da başvurulmuştur. Bu çalışma bir belgesel tarama çalışmasıdır.

Çalışmada bütün şûra kararlarına ulaşılmış, konu ile ilgili diğer dokümanlar, komisyonların çalışmaları, yapılan konuşmalar, öneriler incelenmiştir. Ayrıca konuyla ilgili başlıca belge ve bilgilere ulaşmak için belgesel tarama yöntemine başvurulmuştur.

\section{Bulgular}

\section{Millî Ĕgitim Şûraları}

Türkiye’de millî eğitim sistemine yön vermek, eğitim-öğretimle alakalı problemleri belirlemek, incelemek, çözümüne dair öneriler getirmek ve bunlarla ilgili kararlar alarak bakanlığa sunmak üzere ilki 1939'da olmak üzere 'Millî Eğitim Şûraları' toplanmıştır. Bu yönüyle Millî Eğitim Şûraları, Türkiye'deki eğitim sistemine ait mevcut sorunların tartışıldığı, çözüme dair kararların alındığı, belirli zamanlarda toplandığı, Millî Eğitim Bakanlığının en önemli danışma organıdır.

Milli Eğitim Şûraları, ilgili bakanlığın örgütsel yapısını düzenleyen 789 sayılı yasa üzerinde yapılan çalışmalar esnasında ilk gelişmeler ortaya çıkmıştır. Şuralara ait ilgili yönetmelik ise 1926 yılında yine bu çalışmaların yapıldığı zamanda hazırlanmıştır. Ancak, 789 sayılı yasada şûraların kuruluşuna yer verilmediğinden, Şuaraların kuruluşu 1933 senesinde yürürlüğe giren 2287 sayılı “Maarif Teşkilatı Hakkında Kanun”un çıkması ile gerçekleşti. 
Yukarıda da söylendiği üzere Millî Eğitim Şûrasının ilk kez toplanması 1939 senesinde olmuştur. Milli Eğitim Şurası, en son 2014 yılında toplanmış ve günümüze kadar 19 şûra düzenlenmiştir. $\mathrm{Bu}$ şûralardan bazıları belirlenen yasal sürelerinde toplantı yapmalarına rağmen, bazı şura toplantıları ise zamanında yapılamamıştır.

Şûralarda alınan kararlar neticesinde Türk eğitim sistemine yeni yönler verilmiştir. Şuralar bu işlevsel görevlerini ifa ederken dönem hükümetlerinin (iktidardaki siyasal parti), sosyo-ekonomik gelişmelerle dış dünyanın etkisi daima gözlenmiştir. Özelliklede dönem hükümetlerinin etkisi büyük olmuştur. Çünkü şûra yönetmeliği gereği alınan kararlar tavsiye niteliğindedir. Şurada alınan kararları uygulayacak organ ise Millî Eğitim Bakanlığıdır. Bu nedenle şurada tavsiye niteliğinde alınan bu kararlar ancak bakanın onayından sonra yasallık kazanmaktadır.

Şûralarda alınan kararlarda Türkiye'de yaşanan sosyal, ekonomik ve siyasal değişim dönemlerine ait önemli izler görülür. Tek Parti Döneminde 1943 yılında yapılmış olan şûra ve alınan kararların uygulanmaları ile çok partili Döneme geçiş sürecinde yapılan şûralar ve çok parti döneminde gerçekleştirilen şûraların karar ve uygulamaya aktarılma seviyeleri farklıdır. 1946, 1960, 1971, 1980, 1997 ve 2002 yıllarında gerçekleşmiş olan toplumsal-siyasal değişimler, döneme ait ideolojilerini de eğitim sistemine ve yapılan şûralara da yansıtmışlardır. Değişim evrelerindeki mevcut iktidarın politikası şûra kararlarının alınmasında etkili olduğu kadar uygulama esnasında, kendi politikalarına uymayan kararlar ise es geçilmiştir.

Sosyal ve ekonomik değişim dönemlerinin de dâhil olduğu, şûraların tamamı için yapılabilecek değerlendirme şöyledir: Eğer iktidardaki siyasal partilerin siyasi ve ideolojik yönelimlerinin şûralara yön vermesi yerine daha çok teknik ve bilimsel yönü ön plana çıkarılabilirse şûralarda alınan kararların Türk eğitim sisteminin sorunlarını çözmek için yetkin olacağ1 ve eğitimde toplumun beklentilerine cevap verebileceği beklenebilir. Ancak eşyanın doğası gereği iktidardaki siyasal partiler kendi siyasal ve ideolojik yönelimlerini şûralara aktarmaya devam edecek olmaları ve ayrıca kararlar uygulamaya aktarılamadığı ya da zamanında aktarılamadığı için bu çalışmalardan beklenen düzeyde verim alınamamaktadır. Yakın gelecekte de bu durumun değişmesi beklenmemektedir. Özellikle alınan kararların uygulamaya aktarılamadığı ile alakalı anlayış, aynı zamanda, şûra kararları için bir uygulayıcı statüde olan Millî Eğitim Bakanlığı ve bakanlarının da dahil edilebileceği müşterek yargılarıdır. Hemen hemen yapılan her şûranın açış konuşmasında, bir başka ifadeyle şûra toplantılarının hemen öncesinde bu olgu bakanlarca dile getirilmiş/itiraf edilmiştir. 
YYÜ Eğitim Fakültesi Dergisi (YYU Journal of Education Faculty), 2019; 16(1):171-201, http://efdergi.yyu.edu.tr

Sonuç olarak; şûraların Türkiye'nin mevcut eğitim sisteminin sorunlarının tespiti, iyileştirilmesi, çözümü ve eğitimin sağlıklı işleyişi gibi konularda önemli kararlar almış olduğu; fakat alınan bu kararların politik ve siyasal yaklaşımlardan arındırılmış şekliyle yaşama geçirilmesi durumunda eğitim sisteminde mevcut yada karşılaşılacak olan sorunların büyük ölçüde çözüleceği ve dolayısıyla eğitim sisteminde ki olabilecek olumlu gelişmelerin neticesinde toplumda da modern ve çağdaş uygarlık düzeyine ulaşılmasında önemli bir aşama kaydedilebilecektir.

\section{Millî Eğitim Şûralarında Eğitimin Finansmanı}

“Birinci Millî Eğitim Şûrası” (1939), eğitimin sadece özel birtakım kısımlarının değil tamamının, Türkiye’nin eğitim sisteminin genel bir değerlendirilmesinin yapılması amacıyla 1939 yılı 17-29 Temmuz’unda, dönemin Millî Eğitim Bakanı olan Hasan Ali Yücel’in komisyon başkanlığında Ankara ilinde toplanmıştır.

“İlk Millı̂ Eğitim Şûrası’nın” toplanış amaçlarından eğitimin finansmanını ilgilendiren iki maddesi şöyledir (MEB, “Birinci Millî Ĕ̌itim Şûrası, 1991”):

-Köylerdeki öğretmen açığının eğitmenlerle giderilmesi,

-Köylülerin katkısıyla köylerde az masraflı okullar açılması,

Alınan kararlar:

-Yardımcı öğretmenlik hakkında yönetmelik kabul edildi.

- Üç yıllık köy okulları beş yıla çıkarıldı.

Şûrada alınan üç yıllık köy okullarının beş yıla çıkarılması kararı ile birlikte öğretmen ihtiyacı artmıştır. Bütün Türkiye'de bulunan yaklaşık 40.000 köy hesaba katıldığında bu karar zaten sıkıntılı olan eğitimin finans sorununa yeni yük getirmiştir. Ancak Köy Enstitüleri için mevcut Kanunu’na göre kuruluşu yapılacak olan köy okullarının tesis edileceği arazileri ile bina inşaatlarının yapımı için köylülerin de katkısının sağlanmasıyla bu finans yükü bir nebze azaltılmıştır. Ayrıca köylerde okullar için arazi bulunması konusunda her zaman gönüllülük esası olmadığından bazı sorunları da beraberinde getirmiştir.

İlköğretimde çalışanların özel idare bütçesinde karşılanan maaş ve yasal haklarına ait masraflar genel bütçeye geçirilmeli, ilköğretimdeki diğer harcamaların ise mahalline bırakılması yönündeki temennisi ise ancak 1948 yılında yürürlüğe girebilmiştir. Bu tarihten sonra ilkokul öğretmenleri artık maaşlarını düzenli alabilmişlerdir. 
1946 yılında toplanan “Üçüncü Millî Eğitim Şûrası’nda” (MEB, “Üçüncü Millî Eğitim Şûrası, 1991”) okullara aynı zamanda finansal destek de sağlayacak Okul- Aile Birliği kurulması, Okul-Aile Birliği kurulan okullarda yine okullara finansal destek sağlayan Okul Koruma Derneklerinin kaldırılması kararı alındı ise de koruma dernekleri 2000'li yıllara kadar varlıklarını sürdürmüşlerdir. Şûra kararlarından, Okul-Aile Birliği Yönetmeliği ise 31.01.1947 tarihinde yürürlüğe girmiştir.

Öğretmenlerin; özlük hakları ve sicil durumlarının günün şartlarına göre gerekli olan değişikliklerin yapılması ve ekonomik durumlarının iyileştirilmesi yönünde alınan karara rağmen bir iyileştirme yapmak mümkün olmamıştır.

1953 yılında düzenlenen “Beşinci Millî Eğitim Şûrası’nda” (MEB, “Beşinci Millı̂ Ĕ̆itim Şûrası, 1991”) bir taraftan ilköğretimi ülkenin en uzak köşelerine kadar yaymak amaçlanırken, ilkokul öğretmenlerinin şehir öğretmen okulları ile köy enstitüleri gibi iki ayrı kaynaktan yetiştirilmemesi gerekçesiyle Köy Enstitülerinin kapatılarak öğretmen okullarına çevrilmesi kararı uygulamaya sokulmuştur. Böylece özellikle işçilik giderleri açısından eğitime yeni finans yükü gelmiştir. Ancak bu uygulama ile -sonuçları itibarıyla- köy enstitüleri projesi ile on beş yılda Türkiye'de okulsuz köy kalmaması hedefinden de vazgeçilmiş olunmuştur.

Yine amaçlanan okul çağında olup da okul dışında kalan çocukları okula kavuşturmak, ${ }^{5}$ çiftli öğretim ve kalabalık sınıf mevcutları için çözüm üretmek, öğretmen açığını giderecek önlemlerle ilgili önerileri de köy enstitülerinin kapatılması ile çelişmektedir. ${ }^{6}$

Öğretmenlerin ekonomik durumlarının iyileştirilerek daha yüksek bir maaşla göreve başlamaları kararı da finansal nedenlerden yerine getirilememiştir.

$\mathrm{Bu}$ şûrada ayrıca anaokullarını yaygınlaştırmak için bazı önlemler alınması, bu bağlamda özel anaokullarını teşvik için devletçe bazı önemli ekonomik destekler, vergi bağışıklıkları sağlanması yönünde kararlar alınmıştır. Böylece devletin/kamunun finans yükü azaltılmak istenmiştir.

“Okullar Arası Sigorta Kurumu” hakkında bir kanunun ilk kez okullar düzeyinde, hastalık ve kazalara karşı çıkarılması düşüncesinin işlenmesi dikkat çeken bir çaba olarak

\footnotetext{
5 “Şûranın yapıldığg yıl il ve ilçelerde okul çağındaki 704.000 çocuktan 186.894, yani, yüzde 27’si, köylerde okul çağındaki 2.090.000 çocuktan 896.682 si, yani, yüzde 43'ü okul dişındaydı.”

6 “İl ve ilçelerde okulların ihtiyaçları ile bütün köylerin okula kavuşması için 1952 de gerekli öğretmen kadrosu 71.000 olmasına karşılık mevcut kadro 42.874.olup 28.126 öğretmene ihtiyaç vardır. Yani, mevcut kadro ihtiyacın ancak yüzde 35'ini karşılamaktaydı.”
} 
eğitim tarihinde yerini almıştır. Böylece her çocuk hastalık ve kazalara karşı sigortalanacaktı. Bunun finansmanını veliler karşılayacaktı. Ayrıca bu sigorta kurumu fakir öğrencilere finansal destek sağlayacaktı. Ancak bu uygulanamayan ir karar olarak kalacaktır.

Özel eğitime muhtaç çocuklarla ilgili komisyon raporunda ise ilginç bir temenni olarak 19 Mayıs Gençlik ve Spor Bayramı törenlerinin para karşılığında halka izlettirilmesi yönündeki dikkat çekici istek şûra üyelerince kabul edilmemiştir. Buradan anlaşılan çok bakanlığın, okulların büyük finansal sorunları bulunmakta olup belki çaredir diye bayramların bile halka paralı izlettirilmesi gündeme gelebilmiştir.

1988 yılında toplanan “On İkinci Millî Eğitim Şûrası’nda” (MEB, “XII. Millî Eğitim Şûrası, 1989”) eğitim finansmanı doğrudan gündem maddesi olarak ele alınmıştır.

Üniversite harcı konusu ilk olarak bu şûrada gündeme gelmişti. Buna göre maddi açıdan durumu iyi olan öğrencilerin, yükseköğrenimin gerektirdiği her türlü harcamaya, bu öğrenim kademesinin kendilerine sağladığı şahsî fayda oranında katılmaları; maddî bakımdan gerçekten yetersiz olan öğrencilerin giderlerinin ise, geçimleri için de gerekli burs veya kredi karşılığında devlete borçlanmaları ve bu borçlarını mezun olup işe girdikten sonra ödemeye başlamaları düşünülmüştü.

Dönemin Başbakanı olan Turgut Özal'ın Şûrayı açış konuşmasında; "Hükümet programımızda eğitim ve öğretimde 1 milyon bilgisayar kullanılması hedef alınmıştır." dese de bu hedef finansal nedenlerle ancak 2010'lu yıllarda tutturulabilmiştir.

Eğitim finansmanı ile ilgili alınan diğer kararlar şunlardır:

“1.Konsolide bütçeden her yıl bütçe kanunları ile Millî Eğitim’e (yükseköğretim dâhil) ayrılan payın yüzde 15'in altına düşmemesi hususunun bir kanun hükmüne bağlanması,”

"2.Özel İdareden, bütçenin hazırlanma yılına göre ili yıl öncesinin geliri dikkate alınarak ayrılan yüzde 20'lik payın artırılması için gerekli mevzuat değişikliğinin yapılması,”

“3.Ortaöğretimde öğrencilerin eğitim harcamalarına katılmalarını sağlayıcı hukuki düzenlemelerin getirilmesi,”

“4.Belediye gelirlerinden de yüzde 10’dan aşağı olmamak üzere Millî Eğitime pay ayrılması için gerekli mevzuat düzenlenmesinin yapılması,”

“5.Millî Eğitim Vakfının, vakıf şirketleri kurarak üretici bir hüviyete kavuşturulması ve sağlanan kaynaklarla eğitim hizmetlerinin yaygınlaştırılması,” 
YYÜ Eğitim Fakültesi Dergisi (YYU Journal of Education Faculty), 2019; 16(1):171-201, http://efdergi.yyu.edu.tr

"5.Okulların her türlü bağış, kurs gelirleri kantin gelirleri ve diğer benzeri mahalli gelirlerinin toplanıp aynı okulda kullanılabilmesini sağlayacak bir mekanizmanın geliştirilmesi için gerekli mevzuat düzenlemesinin yapılması,”

“6.Sanayi siteleri ve organize sanayi bölgeleri içindeki Çıraklık eğitim merkezleri arsalarının kooperatiflerce bedelsiz tahsis edilmesi; ayrıca, organize sanayi bölgelerinde belirli bir kritere göre endüstri meslek liselerinin yapımının sağlanması,”

“7.Özel Kurs ve Dershanelerden, belirli bir oranda pay alınmasının sağlanması,”

“8.Öğretmenlere sosyal imkânlar sağlanması bakımından öğretmenler yardımlaşma kurumunun (ÖYK) kurulmasıdır.”

Yukarıdaki maddelerden eğitimin finans sorununu çözebilecek olan "Konsolide bütçeden her yıl bütçe kanunları ile Millî Eğitim’e (yükseköğretim dâhil) ayrılan payın yüzde 15'in altına düşmemesi hususunun bir kanun hükmüne bağlanması" maalesef son şûranın yapıldığı 2014 yılına kadar uygulama şansı bulamamıştır.

1990 yılında toplanan “On Üçüncü Millî Eğitim Şûrası’nda” (MEB, “Millî Eğitim Şûraları (1939-1993), 1995”) da finansman konusu “yaygın eğitimde yatırım ve finansman” adıyla doğrudan gündem maddesi olmuştur.

Şûrada şu kararlar alınmıştır:

“1.İstihdama yönelik insan gücü eğitim programlarına katılan kursiyerlerden belirli bir katılım ücretinin alınması prensip olarak benimsenerek gerekli düzenlemeler yapılmalıdır.”

“2.Millî Eğitim Bakanlığının bütçeden ayrılan ödenekleri içerisinde yaygın eğitime ayrılan yüzdenin (payın) artırılmalıdır.”

“3.Örgün eğitimin fiziki imkânları ile öğretim kadrolarının yaygın mesleki eğitimde kullanılmalarını kolaylaştırıcı esnek bir yapılanmaya gidilmelidir.”

“4.Yerel yönetim bütçelerinden yaygın eğitim faaliyetlerine katkı sağlayacak yasal düzenlemeler yapılmalıdır."

“5.Yaygın eğitim yapan özel sektör kuruluşları ile gelir getirici yaygın eğitim faaliyeti yapan kamu kuruluşlarının ilgili gelirlerinin belirli bir oranının yaygın eğitim faaliyetlerine kurulacak organizasyonlar vasıtasıyla aktarılması sağlanmalıdır."

1993 y1lında toplanan “On Dördüncü Millî Eğitim Şûrası'nda” (MEB, “On Dördüncü Millî Eğitim Şûrası, 1993”) okul öncesi eğitimin finansmanı ile ilgili şu kararlar alınmıştır: 
1. "Verimliliği artırmak için Millî Eğitim örgütünde yeni düzenlemeler yapmak,"

2. “Okul Öncesi Eğitimi’nde okullaşma oranı yüzde 30 olarak geçekleştirilmelidir.”

3. "Belediyeler, Kamu İktisadi Teşekkülleri, Vakıflar, Dini Kuruluşlar ve diğer özel müteşebbislerin Okul Öncesi Eğitim kurumları açmaları desteklenmeli ve teşvik edilmelidir, vergilendirme azaltılmalıdır.”

4. "Gümrüklerdeki malların satışından elde edilen gelirlerle, yurda giriş ve çıkışlarda kesilen konut fonundan sağlanan gelirlerin belli bir yüzdesi okul öncesi eğitimi fonuna aktarılmalıdır.”

5. “Okul öncesi eğitiminin geliştirilip yaygınlaştırılması, gelişme ve yaygınlaşmanın kurumsallaşması için bir fon kurulmalı; belediye gelirlerinden, mevduat gelirlerinden, eğitim sektöründe kazanç elde eden özel kuruluşlardan alınacak paylar ve eğitim vakıflarından sağlanacak katkılar bu fonun kaynaklarını oluşturmalıdır.”

6. “Okul öncesi eğitiminin yaygınlaştırılmasında yap-işlet-devret modelinden yararlanılmalıdır, denilmesine rağmen bu model hiçbir zaman uygulanmadığı gibi bir daha da gündeme gelmemiştir.”

1996 yılında toplanan “On Beşinci Millı̂ Eğitim Şûrası’nda” (MEB, “On Beşinci Millî Ĕ̌itim Şûrası, 1996”) gündem maddelerinden biri “Eğitim Sisteminin Finansmanı” idi.”

Şûranın toplanış amaçları şunlardı:

“1.İlköğretimde 8 y1llık zorunlu temel eğitime geçmek,"

"2.Örgün ve yaygın eğitim programları arasında geçiş ve tamamlama ilkesine dayalı, yılın her günü ve her saati hizmet verecek okul yapısı oluşturmak,”

“3.Eğitimin parasal sorunlarını çözmek için yeni ve sürekli kaynaklar sağlamak,”

“4.Ortaöğretim ve yükseköğretimde katkı payı uygulamasını, Yedinci Beş Yıllık Kalkınma Planında da öngörüldüğü gibi kurumsallaştırmak, ancak maddi durumları yetersiz öğrenciler için burs ve kredi uygulamalarını yaygınlaştırmak.”

Şûrada alınan en önemli karar olan '8 yıllık temel eğitime geçilmesi' kararı 4306 sayılı yasa ile 1997'de uygulamaya konuldu. Bu, 15. Şûranın hem alınan karar olarak hem de yaşama geçirilmesi bakımından en önemli başarısıydı. Ancak bu uygulama ile yeni okul binalarının yapılması, içlerinin doldurulması ve öğretmen ve diğer çalışanlarının finansmanı açısından devlete büyük yük getirmiştir. Öğrencilerden 'eğitime katkı payı alınması' kararı dışında 
toplumun hemen hemen bütün kesimlerince alınan kararlar olumlu bulunuyordu. Yalnız, 8 yıllık temel eğitim kararı konusunda toplumun önemli bir bölümü uygulamanın $5+3$ biçiminde olmasından yana idi. Karar ve uygulamanın kesintisiz 8 yıl olarak gerçekleşmesi toplumun bazı kesimlerince olumlu bulunmadi.

Uygulamada "velilerden katkı payı alınması" konusundaki rahatsızlık devam etmiş ve sonraki yıllarda mahkeme kararları sonucu kaldırılmıştır.

Alınan kararlardan bir diğeri olan "uzun vadede zorunlu eğitim 18 yaşını kapsayacak şekilde düzenlenmelidir” maddesi de 2012-2013 öğretim yılında yaşama geçirilmiştir.

Finansmanı doğrudan ya da dolaylı ilgilendiren diğer kararlar şunlardır:

“1.Yoğun göç alan illerde eğitim yatırımlarına öncelik verilerek derslik ihtiyacı karşılanmalıdır."

“2.Bahçe, salon, sahne, işlik, kitaplık, laboratuvar, spor salonları ve yüzme havuzu gibi ek ünitelerle birlikte her okul, bulunduğu çevrenin de yararlanabileceği tesisler olarak düşünülmelidir."

“3.Çevredeki eğitim kapasitelerinden de yararlanılarak eğitim kaynakları verimli ve etkili kullanılmalıdır."

“4.Okul bina ve tesisleri tatil dönemlerinde ihtiyaçlar doğrultusunda gelir getirecek şekilde de değerlendirilmelidir (Çay bahçesi, otopark vb. gibi).”

“5.Her okulda bir rehberlik servisi kurmak ve uzman bulundurmak güç olabilir. Bu nedenle, rehberlik ve araştırma merkezlerinin sayısı çoğaltılmalı. Burada yer alan "Her okulda bir rehberlik sevisi kurmak ve uzman bulundurmak güç olabilir” sözünün altındaki neden de doğal olarak finansal problemlerden kaynaklı idi.”

“6.Yükseköğretimde kapasite artırımı için;

a)Vakıf üniversiteleri dışında, özel yükseköğrenim kurumlarının açılmasına yasal olanak sağlanmalıdır. Bu kurumlar Yüksek Öğretim Kurulu denetiminde olmalıdır, denilse de uygulama vakıf üniversiteleri biçiminde devam etmiştir.

b)İhtiyaç duyulan alanlarda ikinci öğretim teşvik edilmelidir.”

“7.Okuma- yazma gibi temel eğitim niteliği taşıyan kurslar dışındaki yaygın eğitim faaliyetlerine katılan kursiyerlerden belirlenecek miktarda "katkı payı" alınmalıdır." 
“8.Siyasal erk, makro kamu kaynaklarının tahsisinde eğitime öncelik verilmelidir.”

“9.Eğitim sektörüne kamu kaynaklarının tahsisi, proje bazında değil, makro düzeyde ele alınmalı ve eğitim kademelerine göre ödenekler toplu olarak tahsis edilmelidir."

"10.Yatırım teklifleri gerçekçi ve yerel ihtiyaçlarla tutarlı programlara bağlanmalı ve bu programların uygulanmasında politik etkiler kaldırılmalıdır."

“11.Yerel yönetimlere yetki devri çerçevesinde, yerel birimlerin öğretmen dağılımı ve yatırımların planlanmasında söz sahibi olmaları sağlanmalıdır. Kaynakların yerinde kullanımı açısından, eğitimde yerel yapılanmaya geçilmeli, yönetici, öğretmen, öğrenci, veli, sendika ve meslek kuruluşlarının eğitim yönetimine katılımları sağlanmalıdır.”

"12.Kamu eğitim harcamaları, tasarruf tedbirleri ve bütçe kesintileri dişında tutulmalıdır. Belediye Gelirleri Kanunu'nda gerekli değişiklikler yapılarak resmi ve özel okullar her türlü harç ve vergiden muaf tutulmalıdır."

"13.Yurtdışında eğitim gören yüksek nitelikli insan gücünün yurdumuza çekilmesi için gerekli teşvik önlemleri alınmalı ve beyin göçünün önlenmesi konusunda Millî Eğitim Bakanlığı çalışmalar başlatmalıdır."

“14.Dış kaynaklı kredilerle ilgili projelerin seçimi ve kullanımında, getirileri ve götürüleri iyi hesaplanmalı, ekonomik ve üretime yönelik olmayan krediler kullanılmamalıdır."

“15.Eğitim politikalarında süreklilik ilkesi hayata geçirilmeli, hükümetten veya kişiden kişiye değişen politikalardan vazgeçilmeli ve kaynak israfı önlenmelidir.”

"16.Döner sermaye sistemi gözden geçirilmeli, döner sermaye işletmeleri iyileştirilmeli, atıl durumdaki döner sermayeler diğerlerine aktarılmalı ve döner sermaye karları özel bir fonda toplanarak eğitim mahallinde doğrudan kullanılır hale getirilmelidir."

“17.Kaynak kullanımında etkinliği artırmak bakımından Mesleki Teknik Ortaöğretim Kurumları ile Meslek Yüksek Okulları arasında bağlantı kurularak, bu okulların tesis ve personelinin ortak kullanımları sağlanmalıdır.”

“18.Kamu eğitim bütçesinin, konsolide bütçe içindeki payı en az yüzde 20, GSMH içindeki payı en az yüzde 8 düzeyine yükseltilmelidir.” 
YYÜ Eğitim Fakültesi Dergisi (YYU Journal of Education Faculty), 2019; 16(1):171-201, http://efdergi.yyu.edu.tr

“19.222 sayılı yasanın daha önce iptal edilen 76-c Maddesi yeniden konularak, Belediye gelirlerinin yüzde 5’i emlak vergisi ile çevre ve temizlik vergisinden pay ayrılmalıdır."

“20.Yeni kaynak yaratmak amacına yönelik olarak Millî Piyango İdaresi, şans oyunları gelirleri ile Türk Hava Kurumu ve Türkiye Diyanet Vakfı gelirlerinden bir bölümünün Millî Eğitim Bakanlığı'na aktarılması sağlanmalıdır."

“21.Özelleştirme gelirlerinin en az yüzde 3'ü eğitim yatırımlarında kullanılmak üzere, eğitim payı olarak ayrılmalı ve bu amaçla ayrı bir fon oluşturulmalıdır."

“22.Küçük ve Orta Ölçekli Sanayi Geliştirme ve Destekleme İdaresi Başkanlığı (KOSGEB) gelirlerinin en az yüzde 5'i mesleki eğitimi geliştirmek amacı ile Millî Eğitim Bakanlığı Bütçesi'ne aktarılmalıdır.”

“23.Sürücü kurslarıyla ilgili her tülü evrak Millî Eğitim Vakfı tarafından bastırılmalı ve gelirinin bir bölümü Millî Eğitim Müdürlüklerine bırakılmalıdır.”

“24.Millî Eğitim Bakanlığı’nın taşınmazları değerlendirilmeli ve böylece daha geniş hizmet verecek gelir kaynakları sağlanmalıdır.”

“25.Özel okullar ve yaygın mesleki ve teknik kurslara vergi destekleri (Gelir ve kurumlar vergisi muafiyeti, düşük oranda KDV uygulaması, eğitim araçlarının Avrupa Birliği ülkeleri dışında kalan ülkelerden gümrüksüz ithali) sağlanmalıdır.”

“Özel okullar ve yaygın mesleki ve teknik kursların işletme giderlerinin azaltılmasına yönelik kamu teşvik tedbirleri alınmalıdır."

“26.Özel okullara kamu sübvansiyonu sağlanmalıdır. Ancak, bu sübvansiyon kamu okullarındaki birim öğrenci harcamalarının yüzde 50'sini aşmamalıdır."

"27.Kaynakların etkin kullanımı ve kamu eğitim bütçesinin artırılmasına karşın, kaynakların eğitim gereksinimini karşılayamaması durumunda ailelerin eğitim giderlerine katılımı (zorunlu eğitimin dışında) gündeme getirilmeli ve maliyetlere katılım payı; ailelerin gelir düzeyi, eğitim kademeleri, okul türleri ve bilim alanlarına göre farklı olmalıdır. Eğitim maliyetlerine katılımın düzenlenmesiyle eş zamanlı olarak, tüm eğitim kademelerinde firsat eşitliğini sağlayıcı düzeyde etkin bir burs ve kredi sistemi oluşturulmalı, parasız yatılılık sistemi yaygınlaştırılmalı.” 
“28.Okullara gelir elde etmek amacıyla yapılan dergi, yardımcı kitap ve diğer araçların alımı-satımı vb. işlemlerde öğretmen ve yöneticilerin aracılık etmesine son verilmelidir.”

"29.Eğitime yapılan bağışların vergi matrahından düşülmesi sağlanmalıdır."

“30.Maliyetleri düşürücü, geniş kitlelere ulaşma özelliği ve öğretim yöntemlerindeki etkililiği göz önüne alınarak, Açık Lise ve Açık Yüksek Öğretim uygulamaları gerekli koşullar sağlanarak etkinleştirilmelidir.”

“31.Gelir ve kurumlar vergisi mükelleflerinden en az yüzde 2 oranında ek eğitim vergisi alınması hususu değerlendirilmelidir."

“32.Eğitim ve öğretimini yabancı dille yapan okullarda okutulan yabancı dil ders kitaplarının ilgili ülkelerden ithal edilmesi yerine, müelliflerce üretilmesi teşvik edilmelidir.”

“33.Genel ortaöğretimde, ikili öğretimin ve kalabalık sınıf mevcutlarının bulunduğu şehirleşme hızının yüksek olduğu yerleşim birimlerinde, eğitim altyapısının öncelikle tamamlanması ve iyileştirilmesi için bu yörelerdeki yatırımlara öncelik verilmeli, inşaatların kısa sürede bitirilmesini sağlayıcı önlemler alınmalıdır.”

“34.Ders kitaplarının, yeniden kullanılmasına olanak sağlayıcı bir sistem geliştirilmelidir."

“35.Eğitim giderleri vergiden düşürülmelidir.”

Şûranın uygulanmas1/sonucuyla ilgili şunlar söylenebilir:

1.Eğitim sisteminin finansmanı hakkındaki alınmış kararlardan olan "siyasal erk kamu kaynaklarının tahsisinde eğitime öncelik verilmelidir, yatırım programlarının uygulanmasında politik etkiler kaldırılmalıdır, kaynakların yerinde kullanılması açısından eğitimde yerel yapılanmaya geçilmeli, yönetici, öğretmen, öğrenci, veli, sendika ve meslek kuruluşlarının eğitim yönetimlerine katılmaları sağlanmalıdı” gibi kararların hiçbiri uygulanmamıştır.

2.Şûrada eğitime kaynak bulma çalışmalarında, temin edilecek kaynaklarda dağınıklık ve fazlaca varyasyon görülmesi karışıklık meydana getireceği gözlenmektedir. Diğer alanların yapılanması için kullanılacak olan kaynakların eğitimin finansmanına ayrılması karmaşaya ve devletin ilgili kurumları arasında da gerginliğe yol açacağı ve bu durumun uygulanamayacağı önceden de tahmin edilebilir. Örnek; “Türk Hava Kurumu”na ait gelirlerin bir kısmının “Millî Eğitim Bakanlığı”na aktarılması, “Küçük ve Orta Ölçekli Sanayi Geliştirme ve Destekleme 
İdaresi Başkanlığı (KOSGEB)” gelirlerinin en az yüzde 5’inin “Millî Eğitim Bakanlığı”na aktarılması gibi.

3.Millî Eğitim Bakanlığına finans sağlamak için yapılan bu gayretlere rağmen bir yandan da eldeki mevcut kaynakların özel okullar için teşvik niteliğinde desteklenmesi ayrıca özel okullardaki öğrenci başına masrafların (kamu okullarında birim öğrenci başına harcanan) \% 50’sinin aktarılmasını getiriyordu. Milli Eğitim Bakanlığı eğitimin finansmanı ve kendi okullarına kaynak aktarımı için aldığı kararları uygulamazken (Millî Eğitim Bakanlığı İlköğretim Okullarına hiç ödenek ayırmamakta ve ortaöğretim kurumlarına ise gereksinimlerinin yarısına kadar bile ödenek ayırmamaktadır. Yaşanan bu durum 21. yüzyıla girilen 2000 yılında da benzerdir). Bakanlığa bağlı okullar kaynak sorunu çekerken ve bu durum eğitimin niteliğini olumsuz olarak etkilerken -anlaşılmaz bir yaklaşımla- özel okullara kaynak aktarılması kararı alınıyor ve derhal uygulamaya geçiliyordu.

$\mathrm{Bu}$ durum, doğadaki, toplumdaki her organizmanın genel işleyiş, yaşama, varlığını sürdürme ilkelerine ters bir tutumdu.

4.Eğitim kurumlarına yapılacak olan bağışların harcama gideri olarak bağış yapanların vergi matrahlarından düşürülmesi kararı uygulamaya sokulamadı.

5.Kararlardan, “Açık Öğretim Lisesi ve Açık Yükseköğretim etkinleştirilip yaygınlaştırılacak” kararları uygulandı̆̆ı gibi bir adım daha atılarak Açık İlköğretim uygulamasına ve Açık Öğretim Lisesi bünyesinde Mesleki Açık Öğretim uygulamasına da geçildi.

6.Yerel yönetimlere yetki verilmesi ve kaynakların yerel olarak kullanılmasını destekleyen; 222 sayılı kanunun daha önce iptal edilen 76-C maddesi yeniden konularak, “Belediye gelirlerinin yüzde 5’i (ile) emlak vergisi ile çevre ve temizlik vergisinden pay ayrılmalıdı’” kararı uygulanamadı.

7.Millî eğitim sistemine ait problemlerin büyük bir kısmını çözebilecek nitelikte olan ancak, hiç uygulanmayan ve yakın bir gelecekte de uygulanması beklenilmeyen karar şöyledir: "Kamu eğitim bütçesinin konsolide bütçe içindeki payı en az yüzde 20, Gayri Safi Millî Hasıla (GSMH) içindeki payı en az yüzde 8 düzeyine yükseltilmelidir.”

Mesleki ve teknik eğitimin gereksinimi olan parasal kaynakları sağlamak ve kaynakların etkin ve verimli kullanılmasını düzenlemeyi amaçlayan 1999 tarihli "On Altıncı 
YYÜ Eğitim Fakültesi Dergisi (YYU Journal of Education Faculty), 2019; 16(1):171-201, http://efdergi.yyu.edu.tr

Millî Eğitim Şûrası'nın” (MEB, “On Altıncı Millî Eğitim Şûrası, 1999”) gündem maddelerinden biri "Meslekî ve teknik eğitimde finansman” idi.

Şûrada şu kararlar alınmıştır:

“1.Mevcut kapasitenin tam gün-tam yıl kullanılması sağlanmalıdır.”

"2.İş çevrelerinin eğitim sisteminin çıktısını kullanan kesim olarak maliyetlerin paylaşılmasına katkılarının çok yönlü olarak arttırılması yolları düşünülmeli; bu konuda katılımcı yaklaşımlar geliştirilmeli.”

“3.Çıraklık ve Mesleki Eğitim Geliştirme ve Yaygınlaştırma Fonu’nun amacına uygun kullanılmasına özen gösterilmelidir.”

“4.Çıraklık eğitiminin meslek standartlarına uygun bir şekilde yapılmasını sağlamak için kurum ve kuruluşlarca açılacak olan İşletmeler Üssü Eğitim Merkezlerine devletin desteği sürdürülmelidir. Meslek kuruluşları, vakıflar ve gönüllü kuruluşlar ile 625 Sayının Kanun kapsamındaki özel öğretim kurumlarının da İşletmeler Üssü Eğitim Merkezleri açmalarına imkân sağlanmalıdır."

"5.Organize sanayi bölgeleri projelendirilirken; çalışanların mesleki eğitim ihtiyacı da projeye dâhil edilmeli ve uygulama bu projeye göre yapılmalıdır."

“6.Özel sektörün mesleki ve teknik eğitim okulları açması özendirilmelidir.”

“7.Toplu iş sözleşmelerinde işletmelerin meslek eğitimi yapmalarına ve mesleki eğitim kurumları mezunlarının istihdamına ilişkin özel hükümler konulmasına özen gösterilmelidir. KOBİ'ler de bu doğrultuda teşvik edilmelidir.”

"8.Öğretmen ve yöneticiler yerel düzeyde okul bazında ve gereksinim olması halinde sözleşmeli olarak istihdam edilmelidir."

"9.Okullara branşlar bazında ve ihtiyaçları oranında öğretmen kadrosu tahsis edilerek ihtiyaç fazlası öğretmen istihdamı önlenmelidir. Arz fazlası mesleki ve teknik öğretmenler, gerekli tamamlama eğitiminden geçirildikten sonra ilköğretime iş eğitimi- teknoloji öğretmeni olarak atanmalıdır."

“10.Millî Eğitim Bakanlığı, cari, yatırım ve transfer ödeneklerinin harcaması tüm eğitim birimlerine en kısa sürede ulaşması konusunda Maliye Bakanlığı ile etkili ve sürekli bir iş birliği yapmalıdır."

"11.Kamu eğitim harcamaları, tasarruf tedbirleri ve bütçe kesintileri dışında tutulmalıdır." 
12. "Mesleki ve teknik ortaöğretim kurumları, tek bir yönetim çatısı altında toplanmalı ve böylece insan kaynaklarının ve maddi kaynakların (derslik, atölye, laboratuvar, spor salonu, donanım ve diğer tesisler) etkin kullanımı sağlanmalıdır.” Başka bir ifadeyle, "benim okulum, benim araç-gerecim, benim laboratuvarım" anlayışı yerine "bizim okulumuz, bizim araçgerecimiz, bizim laboratuvarımız” anlayışı egemen kılınmalıdır.

“13.Mesleki ve teknik ortaöğretim kurumları ile meslek yüksekokulları arasında bağlantı kurularak bu okulların, bina tesis ve donanımlarını ortak kullanmaları sağlanmalıdır."

“14.Kaynak kullanımında yerelleşme ve katılımcılık ilkesinin yaşama geçirilmesine azami özen gösterilmeli.”

“15.Döner sermaye sisteminin iyileştirilmesine yönelik Döner Sermaye Yasası bir an önce çıkarılmalıdır. Fon'a yatırılacak karlar Döner Sermaye Yasası çıkana kadar, mevcut yasal hükümler çerçevesinde ertelenmelidir.”

“16.Mesleki ve teknik ortaöğretim kurumlarının eğitim ve sosyal amaçlı projelerle iç ve dış ihalelerle katılmalarının özendirilmesi, proje üretir ve bunları pazarlar konuma getirilmesi için bazı mesleki eğitim kurumları çekim merkezi olarak donatılmalı ve gerekli personeli sağlanmalıdır."

“17.Ulusal düzeydeki eğitim seferberliği bağlamında, 2000-2010 y1lları arasında, kamu kaynaklarından eğitime ayrılacak payın GSMH içinde en az yüzde 10, konsolide bütçe ödenekleri içinde en az yüzde 25 düzeyinde olması, yasal düzenlemeyle garanti altına alınmalıdır. Bu kaynaklardan, mesleki ve teknik eğitime ayrılan pay yükseltilmelidir.”

18. "Genel bütçeden, eğitime ayrılan ödeneklerin, eğitim kademeleri ve türlerine göre dağılımındaki dengesizlikleri ortadan kaldırmak için, 2547 Sayılı Yasanın 46. maddesinde” düzenlenen ve öğrenci başına düşen “cari hizmet ödeneği” benzeri bir ölçüt oluşturulmalı ve kaynak tahsisi, öğrenci sayısı, öğrenim dallarının nitelikleri, süreleri ve öğretim kurumlarının özellikleri ile ilişkilendirilmelidir.

19. 3308 Sayılı Yasanın 32. maddesi ile oluşturulan "Çıraklık, Mesleki ve Teknik Eğitimi Geliştirme ve Yaygınlaştırma Fonu” Genel Bütçe dışına çıkarılmalı ve Fon amaçlarına uygun olarak kullanılmalıdır. Bu Fon kaynaklarından:

“a)Her yıl Bankacılık Bütçesine bu maksatla konulacak ödeneğin, mesleki ve teknik eğitimdeki öğrenci birim maliyeti ve öğrenci sayısı ile ilişkilendirilmesi,” 
“b)Geliştirme ve Destekleme Fonu'ndan yapılacak aktarmaların, mesleki ve teknik eğitimdeki öğrenci birim maliyeti ve öğrenci sayısı ile ilişkilendirilmesi,”

“c)Yıllık beyanname veren Gelir ve Kurumlar Vergisi yükümlülerinin hesaplanan Gelir ya da Kurumlar vergilerine ek olarak ödedikleri yüzde 10'luk Fon payı hasılatından Çıraklık Fonu'na ayrılan yüzde1'lik meblağın yüzde 3'e çıkarılması,"

d) “5590 Sayılı Yasa'nın ek 3. maddesi gereğince”, Odalar, Borsalar ve Birlikler tarafından eğitim aracı ile bütçelerinden ayrılan payların yüzde 50'si yerine "Bu kurumların üyelerinden aldıkları yıllık ödenti toplamının yüzde 5"inin alınması,

“e)507 Sayılı Yasa'nın 6. maddesi ve 2821 Sayılı Yasa'nın 44. maddesi uyarınca, sendikalarca eğitim amacıyla ayrılan gelirlerin yüzde 50’si ölçüsündeki paylar yerine, bu kurumların üye ödentileri toplamının yüzde 5'inin alınması, konularında yasal değişiklik yapılması sağlanmalıdır."

“20.Fon kaynakları arasına:"

“a) Kamu kurumu niteliğindeki meslek kuruluşları (Baro, Tabipler Odası, Diş Hekimleri Odası, Eczacılar Odası, Mühendis ve Mimarlar Odas1, Muhasebeci, Mili Müşavirler Odası, Yeminli Mili Müşavirler Odaları ve bunların benzerleri) ile birlik ya da üst örgütlerin üyelerinden aldıkları toplam ödentilerin, yüzde 5 'lik bölümünün,”

“b) Profesyonel spor kulüpleri ve şirketlerinin yıllık bütçelerinin yüzde 5'i ile profesyonel sporcuların transfer ücretlerinin yüzde 10'luk bölümünün, alınması için yasal düzenleme yapılmalidir."

“21.Fon'a katkıda bulunan kurum ve kuruluşların Fon yönetimine ve denetimine katılmaları sağlanmalıdır."

“22.3418 Sayılı Eğitim Gençlik, Spor ve sağlık Hizmetleri Vergisinin, DİE’nin belirlediği yıllık enflasyon oranında artırılması, ayrıca, Taşıt Alım Vergisi ile ilgili düzenlemenin yüzde 12'ye, Akaryakıt Tüketim Vergisiyle ilgili düzenlemenin ise, yüzde 5'e yükseltilmesi sağlanmalıdır."

“23.4306 Sayılı Yasa çerçevesinde, ilköğretim giderlerinde kullanılmak üzere başlatılan eğitime katkı payı uygulaması 1 Ocak 2001 tarihinden itibaren, ortaöğretimi yaygınlaştırmak ve geliştirmek amacıyla kullanılmak üzere, 31 Aralık 2005 yılına kadar uzatılmalı ve her yıl enflasyon oranında artırılmalı." 
YYÜ Eğitim Fakültesi Dergisi (YYU Journal of Education Faculty), 2019; 16(1):171-201, http://efdergi.yyu.edu.tr

"24.Mesleki ve teknik eğitime, belediye gelirleri, Emlak Vergisi, Çevre ve Temizlik Vergilerinden belirli bir pay ayrılmalıdır.”

"25.Mevduat faizi, repo, hisse ve borç senedi alım-satımı vb. kar yaratan bütün işlemlerde, ilgili kurum ve kuruluşlarca halen yapılmakta olan yasal kesintiler toplamından, eğitime yüzde 2'lik pay ayrılması ve bu paydan bir bölümünün de mesleki ve teknik eğitime tahsis edilmesi sağlanmalıdır."

"26.Okullara veliler tarafından yapılan her türlü bağış ve katkılarının kayıtlı hale getirilmesine ilişkin düzenlemeler yapılmalıdır."

“27.Ailelerin eğitim giderleri, yıllık gelir vergisi matrahlarından düşürülmeli, KDV oranları indirilmelidir."

"28.Devlet okullarına yapılan bağışlar, vergi matrahından düşürülmelidir.”

“29.Mesleki ve teknik ortaöğretimde 2005-2006 öğretim y1lı için öngörülen yüzde 47’lik okullaşma oranı bağlamında, bu okullara öğretmen yetiştiren fakültelerin (öncelikle yeni kurulanlar olmak üzere) desteklenmesi sağlanmalıdır. Öğrenim ücretleri en az mühendislik fakültesi öğrenim ücretlerinin düzeyine çıkarılmalıdır.”

“30.Millî Eğitim Bakanlığının, merkezî yerlerdeki taşınmazları değerlendirilmeli ve bu yolla elde edilen gelirlerin eğitim hizmetlerinde kullanılması sağlanmalıdır."

“31.Özelleştirme kapsamındaki taşınmazlardan eğitim için uygun olanların, eğitim kurumlarına ücretsiz tahsisi sağlanmalıdır."

Şûra kararlarının uygulanması ile ilgili şunlar söylenebilir:

3.Dönemin Millî Eğitim Bakanı şûrayı açış konuşmasında; "Bugüne kadar şûralarda önemli kararlar alınmış, bir kısmı hayata geçirilememiştir.” diyerek bakanlığının özeleştirisinde bulunmuştur.

$\mathrm{Bu}$ özeleştiri, bugüne kadar yani “On Beşinci Millî Eğitim Şûrasında” kararların uygulanamadığını gösterdiğinden, “On Altıncı Millı̂ Eğitim Şûrası” kararlarının da bölümünün uygulanamayacağının itirafıdır biçiminde değerlendirilebilir.

6. Şûra kararlarından; kayıt dışı çırak çalıştıran işletmelerin, kayıt altına alınmasını sağlayacak önlemler alınmalıdır, kararı ve “okullara veliler tarafından yapılan her türlü bağış ve katkıların kayıtlı hale getirilmesine ilişkin düzenlemeler yapılmalıdır” kararı; ekonomik ve 
toplumsal yozlaşmanın, yolsuzluğun eğitime, Şûraya yansımasıdır, biçiminde değerlendirilebilir.

9. “Onaltıncı Millî Eğitim Şûrasında”, eğitimin temel iki aktörü olan öğretmen ve öğrencilerin yalnızca yüzde 4,39 temsil edilmeleri (yöneticiler okul müdürleri dışında) geniş katılımın demokratik yönünü zedelemektedir. Hâlbuki Türkiye'nin de altına imza koyduğu UNESCO ve ILO sözleşmeleri karar alma sürecinde öğretmen katılımını gerektirmektedir.

10. “Türkiye işveren sendikaları konfederasyonu (TISK) eğitimde, özellikle mesleki ve teknik eğitimde karar alma ve katılımda daha ağırlıklı görev ve sorumluluk almak isteğini şûrada bildirmiştir.”

11. “İş çevrelerinin eğitim sisteminin çıktısını kullanan kesim olarak maliyetlerin paylaşılmasına katkılarının çok yönlü olarak artırılması yolları düşünülmeli; bu konuda katılımcı yaklaşımlar geliştirilmelidir” kararı ile eğitim finansmanında iş dünyasının da sorumluluk alması için adım atılıyordu.

2006 yılında toplanan “On Yedinci Millî Ĕgitim Şûrası'nda” (http://ttkb.meb.gov.tr/www/suralar/dosya/12, erişim: 18.11.2015) okul öncesi eğitimle ilgili eğitim finansmanı konusunda kamunun yükünü azaltıcı bazı kararlar alınmıştır:

“1. Okul öncesi eğitim kurumlarının açılmasında özel sektör teşvik edilmelidir.”

“2. Kaynak aktarımı, arsa ve bina temini konusunda yerel yönetimlere yasal sorumluluk verilmelidir."

“3. Okul öncesi eğitim hizmeti veren kreş, gündüz bakımevi, çocuk yuvaları, özürlüler için rehabilitasyon merkezleri ve benzeri sosyal tesislerin yapılarının geliştirilmesi amacıyla devlet desteği ve teşvikleri artırılmalı ve bu kurumlara vergi muafiyeti getirilmelidir.”

“4. Belediyeler, il özel idareleri, kamu iktisadi teşekkülleri, vakıflar ve diğer müteşebbislerin okul öncesi eğitim kurumları açmaları teşvik edilmeli ve bu kurumlar desteklenmelidir."

Makale kapsamına giren son şûra olan 2014 y1lında toplanan “19uncu Millî Eğitim Şûrası'nda” (http://www.meb.gov.tr/19-mill-egitim-srasi-sona-erdi/tr, erişim: 18.11.2015) eğitim finansmanının yerinden yönetimine ilk adım olarak "Genel bütçeden pay ayrılarak okul/kurum bütçesi oluşturulmalı, okul/kurum yönetimince bunun etkili kullanımını sağlayacak bütün gelir ve harcamalar yasal güvence altına alınmalıdır” tavsiye kararı 
alınmıştır. Bu kararın yaşama geçirilmesi durumunda etkin bir denetim de yapılırsa eğitim finansmanında önemli tasarruflar sağlanacağı beklenmelidir.

\section{Sonuçlar}

Eğitim çeşitli çıktılarının yanı sıra ülkelerin kalkınmasının temel etkenlerinden biridir. Eğitime aktarılan kaynaklar katma değeri yüksek hizmet/ürün olarak karşılığını verir. Ancak gelişmekte olan bir ülke olarak Türkiye' de eğitime aktarılan kaynaklar yeterli olamamaktadır. Eğitimle ilgili bakanlığın en yüksek danışma organı olanı olan eğitim şûralarında da konu gündeme getirilmiş ve çözüm getirebilecek kararlar alınmışken eğitimin finansal sorunları eğitimin en önemli sorunlarından biri olmaya devam etmektedir. Zira eğitim şûraları aldığı önemli kararlara ve bakanlığın en yüksek danışma organı olmasına karşın kararların uygulama yeteneği siyasi iktidarların tutumu ve bütçe imkânları ile sınırlı kalmaktadır. Millî Eğitim Bakanlığı ise bu sorunları çözecek makam olmasına karşın soruların çözümüne yönelik kararlılık ve dinamizmini ortaya koyamamakta ve halen eğitim alanında siyaset/partiler üstü bir devlet politikası oluşturulamamış bulunmaktadır. Bu bağlamda konumuz finansman olmakla birlikte, MEB'deki sorunun sadece bütçe olanaklarından kaynaklanan finansal değil, yönetsel ve siyasal yapı olduğunu da belirtmek gerekir.

Millî Eğitim Şûralarında Türkiye’deki eğitim sorununu çözebilecek, Türk eğitim sistemini geliştirebilecek ve iyileştirebilecek kararlar alınmıştır. Ancak, uygulamaya aktarılma hususunda gerekli olan adımlar atılmadığı/atılamadığı için, eğitime ait mevcut sorunlar da çözülememiştir. Şûralarda alınan kararların önemli bir kısmı, ya hiçbir zaman uygulanmamış, ya bu kararların aktarımı 20-30 sene gibi uzun bir dönemde olmuş, ya da bir iki yıllık gibi kısa süreli uygulamalardan sonra vaz geçilmiş, bazı zamanlar da ise alınan kararların aksi yönde uygulamalar yapılmıştır.

Tek Partili Dönemde eğitimin temel hedefi; fırsat eşitliği sağlayarak her yurttaşa temel eğitim vermek, dahası okur-yazar yapmak, cumhuriyet ideolojisini benimsetmekti. Yurdun en köşe bucakta kalan köylerini de içine alarak her köye okul ve öğretmen sağlanacaktı. Ancak hem yönetim hem de eğitim finansmanı yönünden çok önemli bir eksi 1950 yılında 5 ve daha yukarı yaştaki 17.776.911 olan nüfusun 11.997.046'sı, yani, 12 milyon Türk yurttaşının okuma yazma bilmiyor olmasıdır. Okuma yazma bilenler ise bilmeyenlerin ancak yarısı, 5.779.915 yurttaştır. İlköğretimde yüzde 100 okullaşma hedefinin yakalanabilmesi için Cumhuriyetin kuruluşunun üzerinden altmış y1l geçmesi gerekmiş ve bu hedef, ancak, 1984'te yakalanabilmiştir. 
Temel eğitimde yüzde 100 okullaşmaya 1983-1984 öğretim yılında ulaşılabilirken öte yandan okula kavuşan yurttaşlar da pek şanslı sayılmazlar. Okuma olanağı bulunan ilkokul öğrencilerinin eğitimde de, kalabalık sınıflar ve ikili öğretim nedeniyle nitelik giderek düşmüştür. Her geçen yıl iyileşme getireceği yerde, durum tersine dönmüştür. İlkokulda \% 100 okullaşma, 1983-1984 öğretim yılında gerçekleştirilmiş, ancak ikili, üçlü öğretim planlı dönemde sona erdirilememiştir. İkili öğretimin 2000’li yıllarda bile sona erdirilmesi bir yana ikili öğretimde öğrenim gören öğrenci sayısı her yıl artmıştır.

Köylere gelince, 1952-1953 öğrenim yılı başındaki geçici rakamlara göre 18.561 köy okuldan yoksundur. Köylerde zorunlu öğrenim çağındaki 2.090.000 çocuktan 896.682 çocuk (çağ nüfusunun yaklaşık yarısı) okulsuzdur.

Buna bir çözüm olarak yapılandırılan Köy Enstitüsü sisteminde, devlet köylere yalnız öğretmen ve malzeme gönderiyor, köylü kendi arazisini bağışladığı gibi okulun yapımını da yapmakla yükümlü tutuluyordu. Böylece devletin finansal yükünü azaltıyordu. Eğitim finansmanı açısından devlete tasarruf imkânı sağlamasından daha da önemlisi okulsuz ve öğretmensiz köy kalmaması için Türk eğitim sisteminin bir buluşu olan köy enstitüleri daha hedeflerine ulaşmadan İnönü döneminde köy enstitülerine muhalif görüşleriyle tanınan Reşat Şemsettin Sirer Millî Eğitim Bakanlığına getirilerek enstitülerin önü kesilmiştir. Bundan gereken toplumsal yarar sağlanamamıştır. Çok partili döneme geçildikten sonra 1953'te toplanan Beşinci Şûra, Köy Enstitülerini kapatma kararı almış, fakat bu boşluğu dolduracak yeni bir yapı ortaya koyamamıştır

Tek partili dönemde eğitime ayrılan finans kaynaklarının yetersizliğinde dışarıya ödenmekte olan Düyun-1 Umumiye borçlarının da büyük etkisi vardır. Örneğin 1942 bütçesinde MEB bütçesi 27.653.734 lira iken Düyun-1 Umumiye pay1 95.279.219 liradır. Duyun-1 Umumiye için ödenen para millî eğitime ayrılan payın üç dört katıdır. Bu durumda, genç cumhuriyetin yöneticileri, şûra kararlarını uygulayanlar ne yapabilirdi sorusu geliyor.

Tabii şûralarda alınan kararlardan uygulamaya aktarılanlardan olumlu gelişmeler de yaşanmıştır; üç sınıflı köy okullarının beş sınıfa çıkarılması, liselerin öğrenim süresinin dört yıla çıkarılması, okul-aile birliklerinin kurulması, köy enstitülerinin kurulması gibi.

Beşinci Şûra'da hem ekonomik sıkıntı içerisindeki çocuklara finansal destek sağlayacak hem de tüm öğrencilere sağlık sigortası sunacak okullar arası sigorta kurumu kararı alınmış ama uygulamaya geçememiştir. Aynı şûrada ele alınan anasınıflarının yaygınlaşması için teşvik verilmesi gündeme getirilmesine rağmen ilerleme sağlanamamıştır. 
Eğitimin finans problemleri her nedense çok partili döneme geçildikten sonra uzun süre Millî Eğitim Şûralarında gündeme gelmemiştir. Ancak bu dönemde de eğitimin finans sorunu bütün ağırlığı ile devam etmiştir. Türkiye ilk kez üçlü eğitimle bu dönemde tanışmıştır. Uzun aradan sonra ilk kez 1988 yılında toplanan On İkinci Şûra’da eğitimin finansmanı ele alınmıştır.

Yükseköğretimin finansına vatandaş katkısı sağlamak üzere üniversite harcı konusu ilk olarak bu şûrada gündeme gelmiştir. Bu karar hemen uygulanmıştır. Ortaöğretimde öğrencilerin eğitim harcamalarına katılmalarını sağlayıcı hukuki düzenlemelerin getirilmesi kararı alınmasına rağmen bu karar yaşama geçirilmemiştir.

Dönemin Başbakanı Turgut Özal Şûrayı açış konuşmasında; "Hükümet programımızda eğitim ve öğretimde 1 milyon bilgisayar kullanılması hedef alınmıştır." dese de bu hedef finansal nedenlerle ancak 2010'lu yıllarda tutturulabilmiştir.

Bu şûrada ilk kez eğitimin finansman sorununu büyük ölçüde çözebilecek bir karar alınır: “Konsolide bütçeden her yıl bütçe kanunları ile Millî Eğitim’e ayrılan payın yüzde 15’in altına düşmemesi hususunun bir kanun hükmüne bağlanması”. Ancak bu karar da uygulama şansını elde edemez.

1996 yılında toplanan “On Beşinci Millî Eğitim Şûrası” ile sekiz yıllık zorunlu eğitime geçilmesi kararı alınmış ve ertesi yıl da uygulamaya konulmuştur. Çeşitli şûralarda alınan kararlardan biri olan 12 yıllık zorunlu eğitim ise 2012-2013 yılında başlamıştır. Her iki oluşum da yeni okul, donanım, öğretmen vb ek finansal yükler getirmiştir. Eğitimin finansal sorununu ağırlaştıran bir etken olurken çözüm olarak ikili eğitim gündeme gelmiş ve yaşama geçmiştir.

“On Beşinci Millî Eğitim Şûrası'nda” alınan kararların: “Özel okullar ve yaygın mesleki ve teknik kurslara vergi destekleri (Gelir ve kurumlar vergisi muafiyeti, düşük oranda KDV uygulaması, eğitim araçlarının Avrupa Birliği ülkeleri dışında kalan ülkelerden gümrüksüz ithali) sağlanmalıdır" ve "Özel okullara kamu sübvansiyonu sağlanmalıdır. Ancak, bu sübvansiyon kamu okullarındaki birim öğrenci harcamalarının yüzde 50'sini aşmamalıdır” uygulanması ile özel okul sayı ve oranlarında artış görülmüş ve bu artış eğilimi devam etmektedir. Ancak devletin kendi okullarına yeterince kaynak aktarmazken özel okullara bu tür teşvik ve destekleri eleştiri konusu olmaktadır.

$\mathrm{Bu}$ yöndeki şûra kararlarından önce zaten özel okulları destekleyen mevzuatlar da çıkarılmıştı. İlk önemli düzenleme 18.03.1985 te yürürlüğe giren ‘Özel Öğretim Kurumlarına Yapılacak Mali Yardım Yönetmeliği olmuştur. Hem yeni ekonomik ve toplumsal yönelim 
(Liberal Ekonomi) hem de yönetmelikle sağlanan teşviklerin etkisiyle bu yıllardan sonra özel okulların sayıları artmıştır. Aynı zaman hükümet programları ve kalkınma planlarında da özel öğretim kurumlarının teşvik edilmesi planlanmıştır.

Millî Eğitim Bakanlığının meslekî teknik eğitimle ilgili bir yayınında özel eğitimle ilgili şu görüşlere yer verilmiştir:

“Özel okullarda okuyan öğrencilerin eğitim harcamalarının bir kısmını vergi iadesi, muafiyet, burs ve benzeri yollarla sübvanse etmek; yükseköğretimde vakıf üniversitelerinin eğitim bütçelerinin bir kısmının devlet tarafından karşılanması ile ilgili uygulamadan ilk ve ortaöğretim kademesindeki özel okullarında yararlandırılmasını sağlamak,..” (MEB, Kalkınma Planlarında Mesleki ve Teknik Ĕ̌itim, 1998)

Özel öğretim kurumlarına yapılan yardım ve teşvikler toplumun bir bölümünün ve özellikle resmi okul yöneticisi ve öğretmenlerinin tepkisini çekmektedir. Tepkilerin ortak yönü, devletin ‘kendi öz okulları’na ödenek ayırmazken/ayıramazken özel okullara neden kaynak aktardığ 1 biçimindedir.

Sonuç olarak devlet okulları geleneksel nitelik ve nicelik sorunları ile yaşamaya devam etmektedir.

Paralı eğitimle 1980’lerde YÖK ile üniversitelerde tanışan Türkiye, 1990’ların sonlarına doğru eğitime katkı payı adı altında ortaöğretim ve ilköğretimde de tanıştı. 1996 yılındaki On Beşinci Şûra'da alınan sekiz yıllık zorunlu eğitime geçiş kararının 1997'de uygulama geçilmesi ile birlikte oluşan yeni durumun getirdiği finansal yükü karşılamak için iki yol kullanılmıştır: Birincisi 16 Ağustos 1997 tarihinde kabul edilen 4306 sayılı yasa ile "bazı kâğıt ve işlemlerden eğitime katkı payı alınması hakkında kanundur. İkincisi her türdeki okullarda okuyan öğrenci velilerinden eğitime katkı payı adı altında para toplanmasıdır. TÜSİAD Eğitim Raporunda (1990) 'ilköğretim parasız olmalıdır' denilmektedir. Kapitalist liberal ekonominin güçlü örgütü Türkiye Sanayici ve İşadamları Derneği (TÜSİAD) bile ilköğretimin parasız olmasını savunuyor. Ama bakanlık 1997 yılından beri 'Katkı Payı' adı altında ilköğretimi parasız olmaktan çıkarmıştır. Özellikle ilköğretimle ilgili olarak Anayasa'da temel eğitimin parasız olduğu 'hükmü ile çeliştiği' gerekçesiyle uygulamanın iptal edilmesi ile ilgili mahkeme kararlarından sonra -yasal olarak- bu uygulamadan vazgeçilmek zorunda kalınmıştır. Ancak fiili olarak veli katkısı bir şekilde üstelik gönüllülük esası gözetilmeden velilerden alınmaya devam etmektedir. 
Yukarıda da söylendiği üzere şûra kararları uygulanamamıştır. Aslında bunca toplanan şûralar ve buralarda alınan onlarca karardan yalnızca bir karar; On Altıncı Şûra' da alınan "2000 -2010 yılları arasında kamu kaynaklarından eğitime ayrılacak payın GSMH içinde en az yüzde 10 konsolide bütçe ödenekleri içinde en az yüzde 25 düzeyinde olması yasal düzenlemeyle garanti altına alınmalıdır” kararı yaşama geçirilebilseydi, eğitimin cumhuriyet tarih boyunca birikmiş finansal sorunları çözülmüş olurdu. Ancak maalesef bu yapılamadı.

Yukarıdaki karar her ne kadar hoş bir söylem olsa da bunun için ülkenin mevcut iç ve dış borçları ile az gelişmiş bir ekonomik yapının zaten sorunlu olan durumu buna izin verebilir miydi sorusunu da sormak gerekir. Ancak yapılabilecek ve yapılması alınan kararlara rağmen ertelenen ya da gündemden çıkarılan kararların mevcudiyeti de ayrıca sorgulanmalıdır.

Örneğin “On Altıncı Millî Eğitim Şûrası'nda” alınan eğitimin finansal sorunlarına kısmen de olsa çözüm getirebilecek bir yaklaşım olarak "İş̧ çevrelerinin eğitim sisteminin çıktısını kullanan kesim olarak maliyetlerin paylaşılmasına katkılarının çok yönlü olarak artırılması yolları düşünülmeli; bu konuda katılımcı yaklaşımlar geliştirilmelidir” kararı neticesinde eğitimin finansmanı için iş dünyasının da sorumluluk alması yönünde adım atılıyordu. Yine bu şûrada, Türkiye ekonomisinin işveren cephesindeki en büyük iki örgütlü yapısı, “Türkiye İşveren Sendikaları Konfederasyonları” ve “Türkiye Esnaf ve Sanatkârlar Konfederasyonu”, kurumlarıyla ilgili yasaların uygulanmasının izlenmesi ve yasaların geliştirilerek işverenlerin, eğitim finansmanına daha fazla katılmalarının sağlanmasının gerekli olduğunu belirtmişlerdir. Görüleceği üzere maliyeti üstlenecek iş dünyasının da bu konuda istekli olmasına rağmen uygulanamayışı Türkiye için kayıptır. Uygulanamayaşındaki temel neden, bakanlıktaki bürokrasi ve hantal yapı ile sıklıkla hükümet ya da bakanların değişmesi neticesinde bakanlığa ait alt birimlerdeki üretimi ve verimliliği düşürmesidir. Netice itibarıyla bu süreç geliştirilememiştir.

Şûralarda eğitimle alakalı hemen hemen her konuda kararlar alınmıştır. Ancak eğitimin doğrudan etkilendiği 'nüfus etkeni' göz ardı edilmiştir. Eğitim üzerinde maddi sorunlar kadar önemli olan ve parasal sorunların da kaynağını oluşturan nüfus artışı konusu irdelenmemiştir. Türkiye’deki nüfus artış hızının yüksek olması eğitime ayrılan kaynakların yetersiz olmasına da direkt olarak etki etmektedir.

Şûralarda, Türkiye eğitim sistemi, mevcut eğitim problemlerinin çözümünde nüfus artış hızının etkisini görmeyerek, büyük bir tarihi yanılgıya düşülmüş ve daha üst düzeyde çözüm üretecek Şûralar ne yazık ki bu durumun göz ardı edilmesiyle eğitime dair çözümler konusunda 
kısır bir döngü içerisinde boğuşup durmuşlardır. Bu olgu aynı zamanda ikilemdir. Eğitim seviyesi düşük olan ülkelerdeki nüfus artış hızı yüksektir ve bu toplumların kaynaklarını da kontrolsüz nüfus artışları yutmaktadır.

Türkiye’nin gelecekteki nüfus planlaması bilimsel yöntemlere göre yapılmalıdır. Oysaki her köye bir okul sloganıyla -özellikle 1980-1995 yılları arasında köylerin nüfusu ve nüfus hareketleri dikkate alınmadan okullar yapılmıştır. Okulun eğitim-öğretime başlamasının üzerinden on yıl sonra okula gidecek öğrencinin bulunamayışından köy okullarının büyük bir kısmı kapatılmıştır. Küçük köylerdeki bu okullar şimdilerde (2000) ahır, kümes, depo olarak kullanılıyor. Büyük çoğunluğu ise yıkık birer viraneye dönmüştür.

Atıl durumda bulunan bu okulların ülke ekonomisinden götürdükleri toplam değer milyonlarca dolarla ölçülebilir. Bu atıl durumda bulunan okullarla ilgili olarak ulusal ekonomiden götürdükleri tutar ve değerle ilgili bir araştırma yapılarak bundan bir ders çıkarılmalıdır.

Millî Eğitim Şûraları, 70 yıllık deneyimi ve birikimi ile Türk Eğitim Sitemine yön vermişlerdir. Eğitim alanında en önemli danışma organı olarak gelenekselleşmiş ve bu geleneğini 21. yüzyıla yüz akıyla aktarmışlardır. Şûraların etkisini kısıtlayan üç temel unsur vardir:

Birincisi ve en önemlisi; şûraların yaptırım gücü olmamasıdır. İkincisi; şûralar partiler üstü bir yaklaşımla ele alınması gerekirken, zaman zaman yapıldıkları dönemde görevde olan hükümeti oluşturan siyasal partinin/partilerin etkisinde kalmaktadır. Her ne kadar seçimle gelen üye olsa da, şûra üyelerinin ağırlıklı olarak bürokrat ve yöneticilerden oluşan yapısı bu sonucu doğurmaktadır. Üçüncüsü; şûraların demokratik bir yapı ve işleyişe sahip olmamasıdır. Şûra gündemini, eğitimin birinci derecede tarafları olan öğretmen ve diğer eğitim çalışanları, öğrenciler ve veliler oluşturmamaktadır. Şûra üyeleri olarak, eğitim hizmetini üretenler ve tüketenler ağırlıkları oranında temsil edilmemekte ve 'göstermelik' olarak şûralarda yer almaktadırlar.

Bir başka konu eğitimin finansmanında sağlanacak kaynaklarda mevcut ve hedeflenen kaynak çeşitliliğine/karmaşasına son verilmesidir. Örneğin önceki bölümlerde verilen “On Altıncı Millî Eğitim Şûrası'nda” alınan kararlara bakıldığında onlarca gelir kaynağı tahsisi görülmektedir. Bunun yerine daha az sayıda ama gerçekleşebilir hedefler ortaya konulmalıdır. Böylece hem gelir karmaşasına son verilecek, hem de olası gelirler daha net görülerek ona göre bütçeler oluşturulabilecektir. Gerçi bunun çözümü yine şûralarda dile getirilmiştir. "19uncu 
YYÜ Eğitim Fakültesi Dergisi (YYU Journal of Education Faculty), 2019; 16(1):171-201, http://efdergi.yyu.edu.tr

Millî Eğitim Şûrası'nda” eğitim finansmanı için “Genel bütçeden pay ayrılarak okul/kurum bütçesi oluşturulmalı, okul/kurum yönetimince bunun etkili kullanımını sağlayacak bütün gelir ve harcamalar yasal güvence altına alınmalıdır" kararı gelir ve harcama çeşitliliği/karmaşasına son verecek bir uygulama olarak önerilmiştir.

Sonuç olarak şûralar yukarıda belirtilen sorunlardan kendini arındırabilirse eğitimin finansal sorunları da dâhil birçok sorunu çözebilecektir.

\section{Makalenin Bilimdeki Konumu}

Sosyal Bilimler Eğitimi/Tarih Öğretmenliği

\section{Makalenin Bilimdeki Özgünlüğü}

Literatürde Millı̂ Eğitim Şûraları konusunu inceleyen çalışmalar olsa da az sayıdadır. Özelde Millî Eğitim Şûraları ve eğitimin finansmanı konusunu araştıran, inceleyen bir çalışma bulunmamaktadır. Bu çalışma ile bu boşluk doldurulmak istenmiştir.

\section{Kaynaklar}

Adem, M. (1993). Ulusal Ĕ̌gitim Politikamız ve Finansmanı. Ankara: Ankara Üniversitesi Eğitim Bilimleri Fakültesi Yayınları.

Başgöz, İ. (1995). Türkiye’nin Eğitim Çıkmazı ve Atatürk. Ankara: Kültür B. Yayınları. http://ttkb.meb.gov.tr/www/suralar/dosya/12, erişim: 18.11.2015. http://www.meb.gov.tr/19-mill-egitim-srasi-sona-erdi/tr, erişim: 18.11.2015.

Maarif Vekilliği 1939 Mali Yılı Bütçesi ve Müzakere Zabıtları. (1939). İstanbul: Maarif Matbaas1.

Maarif Vekilliği 1942 Mali Yılı Bütçesi ve Müzakere Zabıtları. (1942), Ankara: Maarif Matbaası.

MEB, (1991). Beşinci Millî Eğitim Şûrast. İstanbul: Millî Eğitim Basımevi.

MEB, (1991). Birinci Millî Eğitim Şûrası. İstanbul: Millî Eğitim Basımevi.

MEB, İlköğretim Kanunu Tasarısı'nın Gerekçeleri. (Tarihsiz). (222 Sayılı İlköğretim ve

Eğitim Kanunu- 12.1.1961), Ankara: Maarif Vekâleti Yayınları.

MEB, (1998). Kalkınma Planlarında Mesleki ve Teknik Eğitim, Ankara.

MEB, (1995). Millî Eğitim Şûraları (1939-1993), Ankara: Millî Eğitim Basımevi.

MEB, (1999). On Altıncı Millî Eğitim Şûrası, İstanbul: Millî Eğitim Basımevi.

MEB, (1996). On Beşinci Millî Eğitim Şûrası, İstanbul: Millî Eğitim Basımevi.

MEB, (1993). On Dördüncü Millî Ĕ̆itim Şûrası, İstanbul: Millî Eğitim Basımevi.

MEB, Üçüncü Millî Eğitim Şûrası, Millî Eğitim Basımevi, İstanbul 1991, s. 1x, vd.

MEB, (1989). XII. Millî Eğitim Şûrası, İstanbul: Millî Eğitim Basımevi. 
Öztürk, K. (1968). Türkiye Cumhuriyeti Hükümetleri ve Programlarl, İstanbul: Ak Yayınları.

\section{Summary}

When it comes to training finance, it is the resource / creation for training and the efficient and fair use of these resources. If education finance is considered as an economic activity, this is a long-term investment. It is not possible to see results in a short time. Again, in addition to developing the standard of living of individual citizens in economic terms, perhaps more important is one of the corner stones for raising necessary the welfare of the country. Another point is that education is being one of the primary tasks to this state and cannot be viewed as an economic activity. The state is obliged to provide at least basic education to every its citizen. Economics cannot deprive any of its citizens from basic education by financing or other reasons.

The financing of education is one of the most important problems for all countries. This problem in less developed countries can become an important vital problem. Underdeveloped countries had to breast current financial problems besides new financial problems brought about by population growth. While some developed countries may face idle capacities with negative population growth, underdeveloped countries have to make new investments for new schools and teachers for hundreds of thousands and millions of people annually added to their populations every year. Making a new school is not only about building a school building, but maybe increasing more investment for each investment item in the school building, ranging from student desks, information technologies, laboratories, classrooms to educational materials. In addition, the operating costs are not to be underestimated. In addition, it is necessary to add employment expenses of teachers and other education workers in schools.

The fact that such investments are made for financing the education, the growth and development of the country's economy, the increase of qualified workforce, social consciousness and social peace, as well as to provide output, as said above is the obligation to the state.

Usually public resources for education financing in Turkey are used. Although the contribution of private enterprises, classrooms, foundations and institutions is increasing day by day, it is mostly the initiative and responsibility of the state. Donations, contributions, 
participation in expenses, indirect contributions of the public, such as mortar, are also of considerable size. Another problem arises here, these indirect contributions of the people are not always based on volunteerism. In addition to this, the contribution of the public is not equal everywhere, and it causes differences between schools in the region and the image they create and therefore inequalities between schools. Another example of inequality is private schools.

As mentioned above, the financing of education is provided by state resources in large scale, and one of the prerequisites for achieving the desired achievements has been the provision of financial resources to be transferred to education. However, due to the current situation taken from the Ottomans and an underdeveloped economic structure in the later period, the share of the republic's governments to allocate from the budget remained always low. By the 1950s, the share of education from the budget never exceeded 10 percent. In the first years of the Republic, this rate remained at the level of 5 percent. In addition, problems arising from the debts taken from the Ottoman State, the loss of skilled labor force in wars, II. In the years of World War II, the impact of negativities such as the problems brought about by the necessity of defending the majority of the budget has been great. The result of these problems; At the beginning of training issues they care about the founders of the republic, although in 1940 only 8,000 of the 40,000 villages in Turkey was able open in the village school.

Another important factor that financially prevents the progress of education, especially the development of primary education, is to leave the expenses of primary education as an Ottoman heritage to the provincial administrative boards (general councils) without being taken into the general budget. However, in spite of the various arrangements made, the local administrations, which are getting weaker in monetary terms, have been unable to meet the costs of primary education, some provinces have been obliged to reduce their teacher cadre, to close the school and they even wasn't able to pay teacher's salaries. Towards the end of the period, in 1948, with the law no. 5166, the salaries of primary school teachers could be taken into the general budget.

The fact that the foreign debts taken after the 1950s are not used well, even the interest rates of debts cannot be paid in time, as politicians often emphasize, the country is in need of 70 cents in, it does not have enough wealth, it cannot be managed well and it cannot provide the necessary economic development of the country. As a result, the budget balance 
could not be achieved and sufficient resources could not be transferred to other fields as well as to the field of education.

The lack of adequate resources for education has shown in the form of schooling rates, double, triple education, crowded classes, inadequate equipment and educational settings. This structure still continues today. More than half of the schools at all levels except for the universities, including the kindergartens, offer double education in crowded classes.

Throughout the history of the Republic of Turkey the financing of education has always remained a problem. On the one hand, the financial problems are tried to be solved indirectly by the contribution of the public - not in the form of a sense of voluntarism. In addition, it should not be overlooked that a million people participating in the country's population each year puts additional burdens on existing financing problems.

Here is the result; dozens of arrangements have been made regarding the financing of education, and although the subject is discussed in the training parallels, there is no final solution. The difference between the scarce resources of the country and the current demand for financing the education cannot be solved during the Republican period and the education financing problem has not been solved during the period examined and it has always been transferred to the following periods as an important problem to be solved. 